Mester Éva ${ }^{1}$ - Tóth Róbert ${ }^{2}$

\title{
A magyarországi kkv-k aktuális helyzete és finanszírozási lehetőségei
}

\author{
Mester, Éva - Tóth, Róbert \\ Financing SMEs - Prospects in Hungary
}

\section{Összefoglaló:}

Az Európai Unióhoz való csatlakozást követően Magyarországon is az érdeklödés középpontjába helyezödtek a mikro-, kis- és középvállalkozások, többek közt a foglalkoztatottságban betöltött grandiózus szerepe, valamint a hozzáadott érték termelésében is szintén kiemelkedő jelenléte révén. A KKV-k könnyebben találják meg az új piaci lehetőségeket rugalmasságuk, kreativitásuk és alkalmazkodóképességük miatt. Azonban a világ jelenlegi gazdasági szakaszában, amikor késnek a szállítások, a hitelintézetek nehezebben folyósítanak kölcsönöket, a munkaadók dolgozókat bocsátanak el, a vállalatvezetöknek óvatosabban, nagyobb megfontolással szabad döntéseket hozniuk a vállalat menedzselésével, müködtetésével kapcsolatosan. Így a pénzügyi döntések, mind rövid, mind pedig hosszútávon jelentösen befolyásolják a vállalkozás sikeres müködését. Jelen tanulmány célja, hogy egy átfogó képet adjon a magyarországi KKV-szektor jelenlegi helyzetéröl, egyes finanszírozási lehetöségeiröl, valamint a fejlödésnek gátat szabó korlátokról. A tanulmány a magyarországi KKV-k finanszírozási jellemzőit feltáró primer kérdőíves kutatás elméleti alapjait kívánja megteremteni.

Kulcsszavak: kis- és középvállalkozások, versenyképesség, KKV-finanszírozás, pénzügyi válság

\section{Abstract:}

After joining the EU, micro-, small- and medium-sized enterprises came to the focus of attention in Hungary for their grandiose role in both employment and producing added value. Due to their flexibility, creativity and adaptability SMEs find new market opportunities easier. Also, SMEs can find their way and seize appearing opportunities more quickly under rapidly changing, insecure and high-risk circumstances. When analysing the sector, besides the investigation of the external environment, it is also important to focus on internal factors. The success of businesses is not only influenced by their access to financial resources, but also by their internal organisational structure and the standard of their organisational culture. In the present phase of world economy, when transports are delayed, credits are harder to obtain and companies downsize, leaders have to make careful and considerate management and operational decisions. Thus financial decisions have considerable short and long-term effects on the success of business operation. This research paper aims at a comprehensive study of the present situation of the Hungarian SME sector, some of its financing opportunities, as well as factors that hinder its development. Another purpose of the present writing is to lay the theoretical foundations for a primary questionnaire research exploring the financing characteristics of SMEs in Hungary.

Keywords: small- and medium-sized enterprise, competitiveness, SME finance, financial crisis

\footnotetext{
${ }^{1}$ Szegedi Tudományegyetem, Közgazdaságtani Doktori Iskola, Gránit Bank Zrt., Vállalati Üzletág, Ügyvezető lgazgató-helyettes

${ }^{2}$ Szent István Egyetem, Gazdaság- és Társadalomtudományi Kar, Pénzügy MSc, hallgató
} 
Mester Éva - Tóth Róbert

\section{BEVEZETÉS}

Magyarországon a kis- és középvállalkozások (kkv-k) fogalmának meghatározását a 2004. évi XXXIV. törvény szabályozza. A jogszabály szerint azon szervezetek sorolhatók e kategóriába, amelyek létszáma legfeljebb 249 fó, éves nettó árbevétele nem éri el az 50 millió eurót, vagy mérlegfőösszege nem haladja meg a 43 millió eurót, és az állam vagy az önkormányzati közvetlen vagy közvetett tulajdoni részesedése külön-külön vagy együttesen nem haladja meg a $25 \%$-ot. A statisztikai lehatárolás a létszámkategória szerint történik. Ez alapján a legfeljebb 49 főt foglalkoztató szervezetek kisvállalkozásnak - ezen belül a 10 fó alattiak mikrovállalkozásnak -, az 50-249 fővel múködők középvállalkozásnak minősülnek. A Magyarországon múködő vállalkozások döntő része a mikro-, kis- és középvállalkozások csoportjába tartozik- azon belül is a mikrovállalalatok vannak jelentős túlsúlyban. A kkv-k gazdasági szerepe felértékelődött, melynek hátterében elsősorban nagyvállalati folyamatok húzódnak meg, ugyanis költségcsökkentési céllal tevékenységeik jelentős részét kihelyezték. A beszállítók számottevő része a kisebb méretű, rugalmasabban múködő vállalkozások közül kerül ki. Míg eleinte a kkv-k csupán a helyi gazdaságban, azon belül is a lakossági szolgáltatásokban múködtek, addig újabban az innovatív üzleti szolgáltatások területén is megjelentek. Ezek főképp a hálózatra alapozott globális piacra kilépő vállalkozások. A kkvszektor gazdasági szempontból jelentős szerepet tölt be az ország jövedelemtermelésében, a külföldi tőke múködtetésében, a beruházásokban, valamint társadalmi aspektusból a munkahelyteremtésben, foglalkoztatottságban.

\section{A KKV-K HELYZETE MAGYARORSZÁGON}

A Magyarországon működő vállalkozások döntő része - 99,8\% - a kis- és középvállalkozások csoportjába tartozik. A kkv-szektor gazdasági szempontból jelentős szerepet tölt be az ország

ECONOMICA 2015. 1. szám jövedelemtermelésében, a külföldi tőke múködtetésében, a beruházásokban, valamint társadalmi aspektusból a munkahelyteremtésben, foglalkoztatottságban. A 2008-as válságot követően a hazai kkv szektor igazán megerősödni nem tudott. Az ágazat 2009-től 2012 végéig gyenge talajon áltt, azonban 2013tól minimális előrelépés érzékelhető ${ }^{3}$. A kkv szektor által foglalkoztatott létszám a 2008-as szint körül mozog. A hazai kis- és középvállalkozások mintegy 2 millió embernek biztosítanak munkahelyet, a munkavállalók mintegy 73 százalékát foglalkoztatják. A kis- és középvállalkozásokban foglalkoztatottak száma a kilencvenes években dinamikusan növekedett, majd az ezredfordulót követően a növekedés lelassult, majd tendenciáját tekintve mondhatni leállt, így a kkv-k stabilizáló hatást nem tudtak kifejteni a foglalkoztatás terén.

$\mathrm{Az}$ 1. ábra a hazai regisztrált és múködő vállalkozások számának alakulását mutatja 2005 és 2013 között. Jól látható, hogy a múködő vállalkozások közel fele a ténylegesen regisztrált vállalkozásoknak. Számokkal kifejezve mindez annyit tesz, hogy 2005-ben 1.208.780, míg 2013-ban 1.688.169 regisztrált vállalkozást tartottak nyilván Magyarországon. Ez közel 40\%-os növekedést jelent. Azonban a ténylegesen múködő vállalkozások száma 2005ben 707.756, míg 2013-ben 656.458 volt. A legutolsó gazdasági válság kirobbanásának évét követően egy csökkenő tendencia mutatkozik. Lényeges eltérés van tehát a két kategória között, amit az alábbi ábrák jól szemléltetnek.

Az 1. táblázat a 2005. és 2012. közti időszak múködő vállalkozásait mutatja a hazai régiók megoszlásában. A szektort jelentősen meghatározza a területi koncentráció, mindezt jól mutathja, hogy Közép-Magyarországra koncentrálódik a múködő kkv-k mintegy 41\%-a - 10 közül négy szervezet KözépMagyarországon végezte tevékenységét. A többi régió részesedését közel azonos érték jellemzik.

\footnotetext{
${ }^{3}$ A válság sokkal súlyosabb hatást gyakorolt a kis-és középvállalati szektorra, mint a nagyobb vállalatokra.
} 


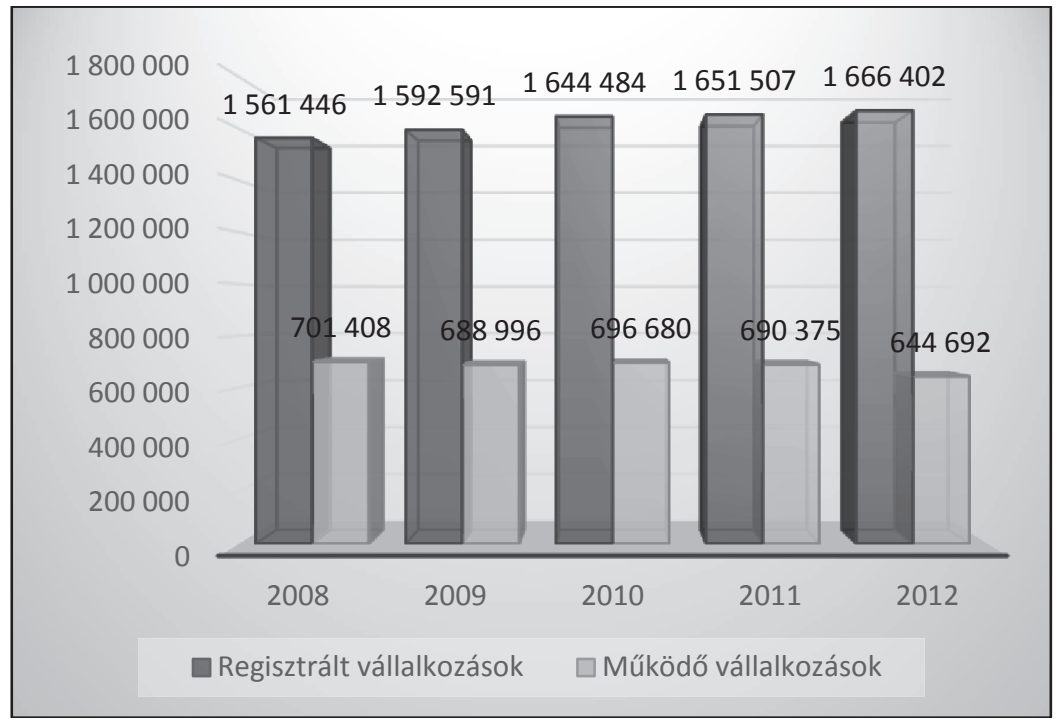

1. ábra. A regisztrált és múködő vállalkozások száma Forrás: http://www.ksh.hu/docs/hun/xstadat/xstadat_eves/i_qpg001.htm (letöltés dátuma: 2015.04.02.)

\begin{tabular}{|c|c|c|c|c|c|c|c|c|}
\hline & 2005 & 2006 & 2007 & 2008 & 2009 & 2010 & 2011 & 2012 \\
\hline Közép- & 273 & 271 & 270 & 277 & 274 & 279 & 279 & 264 \\
\hline Magyarország & 283 & 965 & 786 & 680 & 673 & 430 & 916 & 486 \\
\hline $\begin{array}{l}\text { Közép- } \\
\text { Dunántúl }\end{array}$ & 73886 & 72161 & 71177 & 71403 & 69703 & 70153 & 69077 & 63504 \\
\hline $\begin{array}{l}\text { Nyugat- } \\
\text { Dunántúl }\end{array}$ & 70597 & 69592 & 68820 & 69457 & 68409 & 69034 & 68111 & 62221 \\
\hline Dél-Dunántúl & 61686 & 60432 & 58878 & 59825 & 58644 & 59352 & 58077 & 53558 \\
\hline $\begin{array}{l}\text { Észak- } \\
\text { Magyarország }\end{array}$ & 63306 & 61696 & 60703 & 61091 & 59461 & 59280 & 58234 & 54081 \\
\hline Észak-Alföld & 82696 & 81515 & 78942 & 81170 & 79446 & 80067 & 78868 & 73760 \\
\hline Dél-Alföld & 82302 & 80785 & 78752 & 80782 & 78660 & 79364 & 78092 & 73082 \\
\hline Összesen & $\begin{array}{l}707 \\
756\end{array}$ & $\begin{array}{l}698 \\
146\end{array}$ & $\begin{array}{l}688 \\
058\end{array}$ & $\begin{array}{l}701 \\
408\end{array}$ & $\begin{array}{l}688 \\
996\end{array}$ & $\begin{array}{l}696 \\
680\end{array}$ & $\begin{array}{l}690 \\
375\end{array}$ & $\begin{array}{l}644 \\
692\end{array}$ \\
\hline
\end{tabular}

1. táblázat. A működő vállalkozások száma területi egységek szerint

Forrás: https://www.ksh.hu/docs/hun/xstadat/xstadat_eves/i_qvd004b.html (letöltés dátuma: 2015.04.02.)

A 2. ábra a múködő vállalkozásokat mutatja be a gazdasági ágak megoszlása szerint. A hazai kkv-szektort a szolgáltatási szféra dominanciája jellemzi. (mintegy $80 \%$ ). ${ }^{4}$ A legtöbb vállalkozás -

${ }^{4}$ A nagyvállalatok közel 60\%-át termelő vállalatként tartják nyilván.
133 ezer 866- a kereskedelemben tevékenykedik, ami az összes vállalaton belül mintegy $21 \%$-ot tesz ki.

Az ipar gyújtőfogalomba többek között a feldolgozóipart, az élelmiszeripart, a bányászatot, a gyógyszergyártást, a vegyi anyagok gyártását, a textília, ruházat, bőr, és 
bőrtermék gyártását soroltam, ami együttesen 8\%-t tesz ki. Az építőipart külön kiemeltem, hiszen 2012-ben ebben az ágazatban 55 ezer 544 vállalat múködött, megelőzve ezzel az előbb említett „ipart”. Így mindez együttesen 16,6 \%-t képvisel. Érdemes kiemelni a szakmai, tudományos és múszaki tevékenységet folytató vállalkozásokat, hiszen a vizsgált évben több mint 107 ezer vállalat múködött ebben a feladatkörökben. Ezek azok a vállalkozások, amelyek jelentős tudást felhasználva próbálnak folyamatosan tevékenykedni, mindezeken túl elsősorban ezek a vállalkozások képesek innovatív tevékenységeket folytatni. Egy nemzetgazdaságban rendkívül fontos szerepet kell(ene) juttatni az innovációnak, hiszen megállapítható, hogy jelenleg azok az országok képesek növekedni, amelyek innovációval, kutatás-fejlesztéssel, így tehát tudással versenyeznek. Magyarországra ez jelenleg nem jellemző. Hazánkat elsősorban „összeszerelő országnak" tekinthetjük a jelenlévő autógyárak múködése miatt, amivel azonban tartós növekedés, hosszantartó versenyképesség nem érhető el.

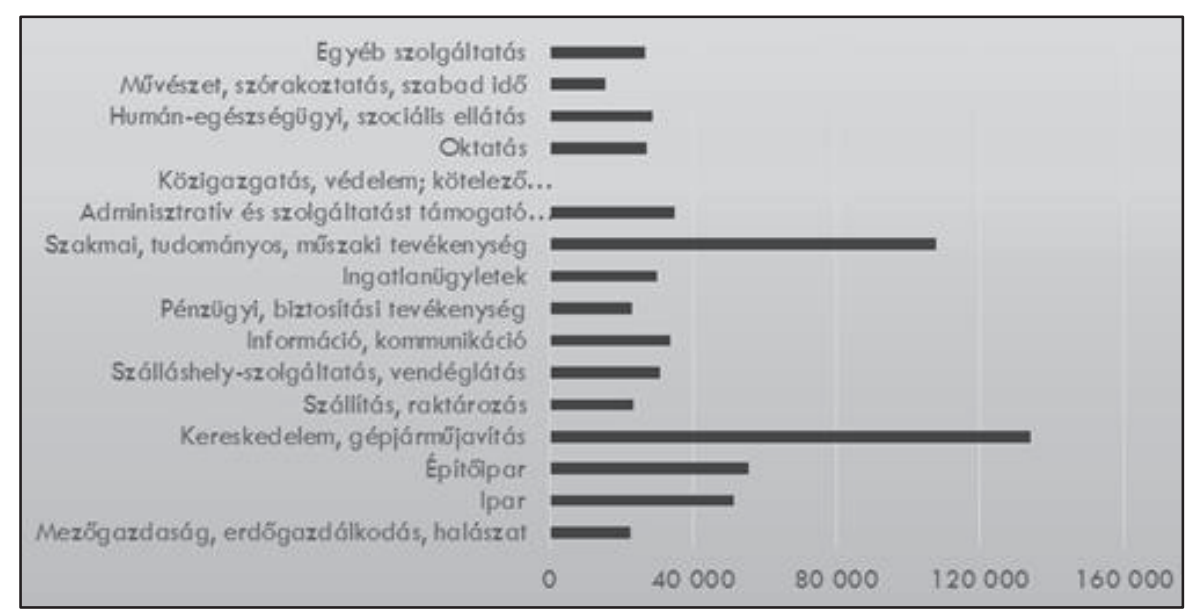

2. ábra: A múködő vállalkozások száma gazdasági ág szerint (2012)

Forrás: http://www.ksh.hu (letöltés dátuma: 2015.04.02.)

\section{A KKV-K SZEREPE FOGLALKOZTATÁSBAN}

A mikro-, kis- és középvállalkozások gazdaságpolitikai jelentősége elsősorban a foglalkoztatottságban betöltött szerepükből fakad. Igen komoly arányú foglalkoztatottságot ölelnek fel a hazai kkv-k - az összes magyarországi foglalkoztatott 71,4\%-a kkv-nál dolgozik, így jelentőségük nem elhanyagolható. Ezt támasztja alá a Gazdasági Együttmúködési és Fejlesztési Szervezet (OECD) több cikkében is olvasható gondolat, miszerint "a kisvállalkozások az innováció, a növekedés és a
A munkahelyteremtés legfontosabb forrásai" (OECD Economic Surveys Hungary, 2014). Így a foglalkoztatás növelésében nagy hangsúlyt kellene fektetni a vállalkozói szektorra, azon belül is a kkv-kra, mivel elsősorban ezek képesek munkahelyeket teremteni. Ehhez pedig szükségszerű a mindenkori kormány intézkedése is, hiszen eredményt elérni ezen a területen is a ", $3 \mathrm{~K}^{\prime \prime}$, úgymint a kormányzat, körponti bank valamint a vállalkozói szféra együttmúködése révén lehetséges. $\mathrm{A}$ vállalkozások méret szerinti csoportosításának leggyakoribb kritériuma a létszám alapján történő besorolás. Magyarországon a 
vállalkozások száma létszám-kategóriaként 2006-2012 között a következőképpen alakult.

A 3. ábra mutatja, hogy a hazai vállalkozások mintegy 95\%-át alkotják a 10 fónél kevesebb alkalmazottat foglalkoztató mikrovállalatok.
Gazdasági húzóerejüket az általuk foglalkoztatottak aránya adja. A kisvállalkozások esetében ez az érték 4\% közül mozog, a fennmaradó $1 \%$ pedig a középvállalkozások és a 250 főnél nagyobb vállalatok alkotják.

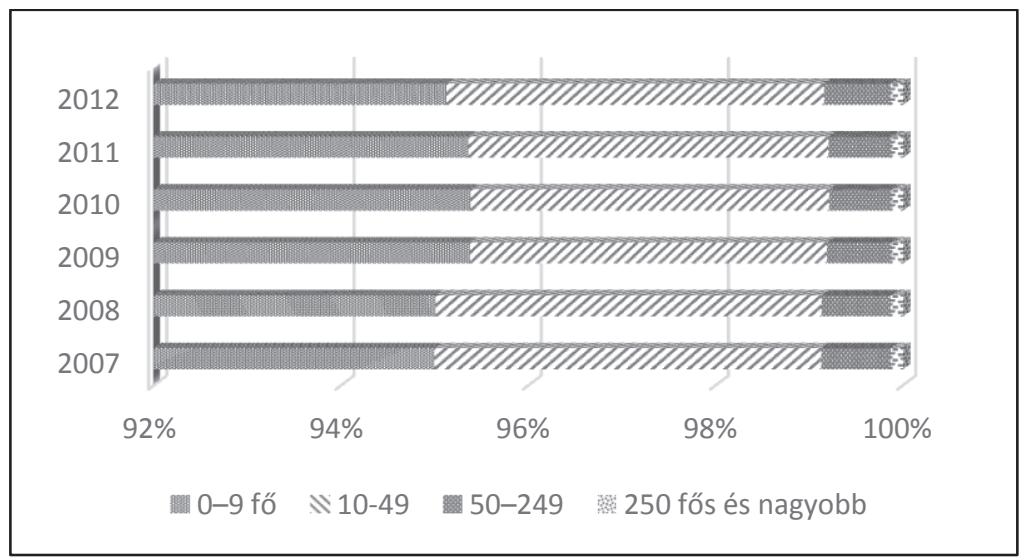

3. ábra: A foglalkoztatottak alakulása (2007-2012)

Forrás: http://www.ksh.hu/thm/1/indi1_2_4.html (letöltés dátuma: 2015.04.02.)

A foglalkoztatottak száma alapján meghatározott méretkategóriák közül minden régióban a legfeljebb 9 fős mikrovállalkozások dominálnak, az ennél nagyobb szervezetek hányada csupán Közép-Magyarországon és DélAlföldön éri el az 5\%-ot. A kkv-k tevékenységi struktúrájában a szolgáltatások szerepe a meghatározó, ami befolyásolja eredményességüket, beruházási, foglalkoztatási képességüket. A kkv-k között a nagyvállalatokhoz viszonyítva kisebb a külföldi érdekeltségű vállalkozások előfordulása. 2012ben összesen közel 28 ezer külföldi tőkével múködő kkv volt az országban. Közöttük az átlagosnál erőteljesebb a területi koncentráció: a szervezetek több mint 70\%-a KözépMagyarországon végezte tevékenységét, és a befektetett külföldi tőke közel kétharmada is itt összpontosult.

Ezen kívül fontos megemlíteni a kkv-k szerepét a foglalkoztatással valamint az oktatással összevetve is. A fentiekben olvasható az ún. „3 K" kombináció, mely egyértelműen kifejezésre juttatja ezen három elem szoros kapcsolatát. A mindenkori kormányzat gazdaságpolitikája magában foglalja azt is, hogy milyen fajta munkaerőre tart igényt a meglévő vállalati struktúra, tehát a múködő cégek. A kisebb és közepes méretű vállalatok egy meghatározó része technológia-fejlesztéssel, innovációval, kommunikációval, informatikával, K+F-el foglalkoznak, ahol pedig elsősorban felsőfokú végzettségú szakemberekre van szükség. A jelenlegi oktatási rendszer azonban csupán a most múködő vállalati rendszert kívánja kiszolgálni munkaerővel, hiszen az összeszerelő üzemek aránya a meghatározó. Ezek az üzemek azonban elsősorban nem felsőfokú végzettségű szakemberekre tartanak igényt, sokkal inkább szakmunkásokat alkalmaznak. Ebből az következik, hogy a felsőoktatásban tanuló hallgatók számát folyamatosan csökkenteni kívánják, és inkább egy-egy szakma elsajátításra ösztönzik a fiatal generációt. Azonban a világ abba az irányba mozdul el, hogy csupán azok az országok képesek gazdasági helyzetük szilárd stabilitásának megteremtésére, fenntartására, 
és a továbbiakban növekedési pályára állni, valamint versenyképes pozícióba kerülni, ahol a lakosság döntő aránya rendelkezik versenyképes felsőfokú végzettséggel.

Továbbá nem szabad megfeledkezni arról sem, hogy a vállalati szféra kínálja a fiatal generáció számára a legtöbb lehetőséget, hiszen ezek a hazai mikro-, kis- és közepes vállalkozások nyújtanak olyan perspektívát, jövőképet a frissen diplomázattak számára, amit kihasználva stabilan tervezhetővé válik az életük. Ehhez szükséges azonban a környezet átalakítása, a vállalkozóbarát feltételek megteremtése. Ezen szektor támogatása elhanyagolhatatlan lenne, hiszen egyértelmúen látható, hogy ez a szektor foglalkoztatta az elmúlt időszakban a társadalom legnagyobb részét és jelenleg is így van. Így feltehetően ha ezen szektor tőkeinjekcióhoz juthatna, további munkahelybővülés lenne realizálható. Itt említem meg, hogy a Magyarország és az Európai Unió között létrejött Partnerségi Megállapodás sorai között nem olvasható, hogy a kkv- szektor azon része, ahol a legmagasabb a foglalkoztatási ráta, tehát a mikrovállalkozások, kapnak majd támogatást a következő 20142020-as ciklusban. A megállapodásban az szerepel, hogy a közepes méretű vállalkozások juthatnak jelentős forráshoz. Ennek hátterében az a kormányzati gondolat húzódik, hogy ez az a vállalati kör, amely leginkább képes exportra is termelni.

\section{A KKV-K GAZDASÁGBAN BETÖLTÖTT SZEREPE}

A kkv-szektor a magyarországi gazdaság egyik legfontosabb eleme közé sorolható. Az előző fejezetben tárgyalt részből következik, hogy a kis-és középvállalkozások valódi jelentősége a foglalkoztatás területére összpontosul, azonban jelentősen befolyásolják a gazdasági teljesítményt is. Mindezt alátámasztja a KSH egyik adata, miszerint a kkv-k 2007-ben a bruttó hazai termék (GDP) 54 \%-t, 2009-ben 55\%-át, míg 2011-ben 56\%-át állították elő. Megállapítható tehát, hogy a hazai kkv-k állítják elő a GDP közel felét, és ez az arány a mikro-, kis- és közepes méretǔ vállalkozások között közel azonos arányban oszlik meg. A KSH 2014. novemberben közzétett adatai szerint 2012-ben a kkv-k összesen közel 45 ezer milliárd forint árbevételt értek el, a teljes vállalkozási szektor teljesítményének 58\%-át. 2011-hez viszonyítva Dél-Dunántúl és Észak-Magyarország kivételével minden régióban nőtt a kkv-k bevétele. Egy szervezet átlagosan 70 millió forintot ért el, ami a vállalkozás méretkategóriájának növekedésével nagyságrendekkel emelkedik. Árbevételük felülmúlta az egy évvel korábbit, ennek ellenére a kkv-k kisebb összeget fordítottak beruházásokra. 2012-ben a fejlesztések nagysága 1450 milliárd forintot tett ki, ami a vállalkozási szektor által megvalósított beruházások értékének 46\%-át képviselte. Közép-Magyarország kivételével a kkv-k fejlesztéseinek döntő hányada három ágazatba került: az iparba, a mezőgazdaságba és a kereskedelembe.

A 4. ábra a GDP termeléshez való hozzájárulást mutatja a vállalati méretkategóriánként. Az ábra alapján megállapítható, hogy a vizsgált időszakban lényeges változás nem következett be a bruttó hozzáadott érték termelésében. A vállalat méretének növekedésével arányosan növekszik a GDP-hez való hozzájárulás aránya is. A kkv-szektor részesedése a GDP-ben nem csökkent a válság óta eltelt időszakban, minimális emelkedés realizálható, azonban ha azt állítjuk, hogy stagnált a bruttó hazai termékben való aránya az is kiemelkedő teljesítménynek számít ilyen turbulens gazdasági időszakban. Amennyiben azonban hozzátesszük, hogy a teljes foglalkoztatotti állomány több mint 70\%-a ebbe a szektorba összpontosul, máris más aspektust mutat. Az ágazati megoszlás alapján a GDP 60\%-a a szolgáltató szektorban keletkezett. A kereskedelem szerepe kevésbé domináns, a kkv-k gazdasági teljesítményéből csupán 1820\%-kal részesedett 2012-ben. ${ }^{5} 2001$ és 2010 között - két év kivételével - a 60\%-t

5 http://www.kaleidoszkop.nih.gov.hu/documents/ 15428/123426/kkv12 (letöltés dátuma: 2014. 12. 26.) 
meghaladta a kkv-szektor részesedése a vállalkozások által realizált bevételnek. 2011 óta viszont ez az érték minimálisan csökkent, 2012-ben az összes árbevétel valamivel több, mint 58\%-a köthető a kis- és középvállalkozásokhoz. A kkv-k gazdaságban betöltött eddig említett jelentősége mellett fontos említést tenni az exportról is, hiszen ők adják az export harmadát. Az elmúlt 15 évben tapasztalható globalizálódás már nem csupán a nagyvállalatokat vonzza magához, hanem megfigyelhető, hogy a kkv-szektor számára is megnyílt a lehetőség ezen világgazdasági forgalomba való bekapcsolódásra. Ide tartozik többek között az exportálás, a nagyvállalatokkal való együttmúködés, számukra történő beszállítás, vegyes tulajdoni körrel bíró vállalkozások alapítása, külföldi kirendeltségek megnyitása, $s$ fontos megemlíteni a más vállalkozásokkal együttműködő kutatást is. ${ }^{6} \mathrm{~A}$ jelenlegi kormányzat is támogatja ezen irányzatot, ezt támasztja alá többek között az is, hogy exportösztönző programot indított az exportképes árukat és szolgáltatásokat előállító kis- és közepes vállalkozások támogatására. Jó lehetőséget jelenthet a vállalkozások számára, hiszen az export növelése együtt jár a termelés növekedésével, ami pedig a munkahelyteremtést vonja maga után. Jelenleg azonban a hazai export túlnyomó részét a nagyvállalkozások adják.

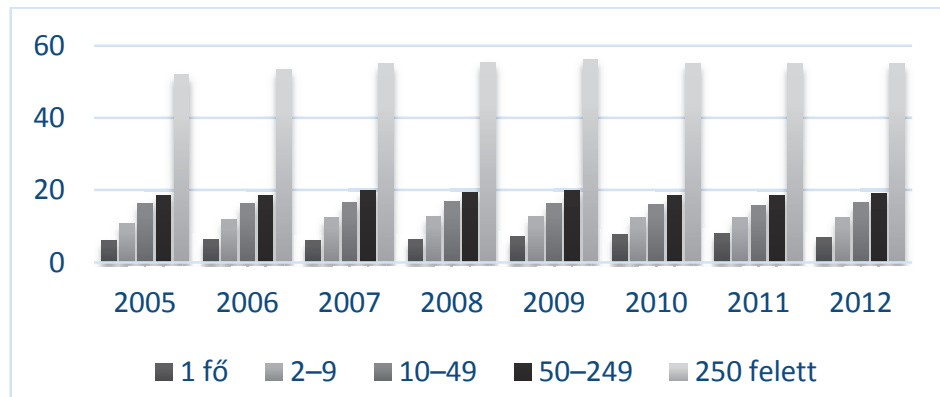

4. ábra: A bruttó hozzáadott érték termeléséhez való hozzájárulás a vállalati méretkategóriánként Forrás: A kis- és középvállalkozások helyzete Magyarországon, KKV Évkönyv 2012, Budapest, 2012

A mikro-, kis- és középvállalkozások itthon fizetnek adót, hazai munkavállalókat foglalkoztatnak, tevékenységük során keletkezett nyereségüket itthon használják fel, fektetik be. Így teljes egészében hozzájárulnak a GDP növeléséhez. A GDP mutató mellett azonban fontos más mutatószámokat is megvizsgálni, hiszen csak a GDP-t elemezve nem kapunk tényleges látképet egy adott gazdasági helyzetről. Ezzel szemben érdemes a GNP, bruttó nemzeti termék mutatót is megvizsgálni, ami sokkal jobb képet ad a gazdas tényleges helyzetről.

\footnotetext{
${ }^{6}$ Szerb László, A haza kis- és középvállalkozások fejlődését és növekedését befolyásoló tényezők a 2000-as évek közepén
}

\section{A MAGYAR KKV-K HELYZETE NEMZETKÖZI ÖSSZEHASONLÍTÁSBAN}

A kis- és középvállalkozások nem csupán hazánkban, de az európai gazdaságban is kulcsfontosságú szerepet töltenek be. Több mint 20 millió kkv tevékenykedik az EU-ban, és mintegy 87 millió embert foglalkoztatnak. Kiemelendő tény, hogy néhány ágazatban, mint pl. az építőipar, a textilipar, bútoripar, sőt ma már ide sorolható a logisztika területe is, a foglalkoztatási ráta eléri, sőt meghaladja a 80\%ot. Az EU 28 országában a vállalkozások jelentős többsége, 93 \%-a mikrovállalkozás, amelyek a teljes foglalkoztatottság 30\%-át jelentik, valamint az árbevétel 17\%-át adják (2. táblázat). 
Mester Éva - Tóth Róbert

A nagyvállalkozások ezzel ellentétben csupán 0,2\%-ot képviselnek az összes vállalkozáshoz viszonyítva, az összfoglalkoztatottak mintegy 33\%-a dolgozik ezen vállalatoknál, és a bevétel 44\%-át adják. 2011-ben minden uniós tagállamban a vállalkozások jelentős része a mikrovállalkozások körébe sorolható. A kis- és középvállalkozások legnagyobb arányban Németországban (18\%), Romániában, Luxemburgban (13\%) és Ausztriában(12\%), míg legkisebb arányban Szlovákiában(4\%) voltak jelen. A nagyvállalkozások aránya az összes tagállamban $0,5 \%$ körül alakult. Az Unió vállalkozásai által előállított, tényező költségen számított bruttó hozzáadott értékből a kkv-k átlagosan 58\%-kal részesedtek, ami 4 százalékponttal magasabb a magyarországinál. A foglalkoztatottakat illetően fordított a helyzet, a kkv-k súlya átlagosan $67 \%$-os, miközben hazánkban felülmúlta a héttizedet.

Összességében az árbevétel, a bruttó hozzáadott érték és a foglalkoztatottak között képviselt súlya alapján a kis- és középvállalkozások szerepe - azon ország adatainak összehasonlítása alapján, melyek közöltek információkat - Észtországban a legnagyobb, az Egyesült Királyságban pedig a legkisebb az uniós tagállamok körében. A hazánkkal szomszédos uniós országokkal összehasonlítva a kkv-k bruttó hozzáadott értékben képviselt súlya négy tagállamban magasabb a magyarországinál. A munkaerőpiaci szerep esetében változatosabb a kép: a kkv-knál foglalkoztatottak hányada a hazaival szinte megegyező vagy annál nagyobb Szlovákiában, illetve Szlovéniában, viszont jóval kisebb Romániában.

Létszám-kategóriák alapján 2011-ben a vizsgálható tagállamok mindegyikében a kkv-k túlnyomó részét a legfeljebb 9 főt foglalkoztató mikroméretű szervezetek képviselték, a legalább 10 fösek hányada 7 országban (a három balti államban, Ausztriában, az Egyesült Királyságban, Luxemburgban és Romániában) közelített meg, vagy haladta meg a $10 \%$-ot. Ez utóbbi érték Magyarországon 5,1\%-ot tett ki, ami az ötödik legkisebb az adatot közló tagországok között és számottevően kisebb az EU-28 átlagát jelentő 7,3\%-nál.

\begin{tabular}{|l|c|c|c|c|c|c|}
\hline & $\begin{array}{c}\text { Mikro- } \\
\text { vállalkozá } \\
\text { s }\end{array}$ & $\begin{array}{c}\text { Kis- } \\
\text { vállalkozá } \\
\text { s }\end{array}$ & $\begin{array}{c}\text { Közép- } \\
\text { vállalkozá } \\
\text { s }\end{array}$ & $\sum$ KKV & $\begin{array}{c}\text { Nagy- } \\
\text { vállalkozá } \\
\text { s }\end{array}$ & $\sum$ Vállalat \\
\hline $\begin{array}{l}\text { Vállalkozások } \\
\text { száma (db) }\end{array}$ & $\begin{array}{c}19,969,33 \\
8\end{array}$ & $1,378,374$ & 223,648 & $\begin{array}{c}21,571,36 \\
0\end{array}$ & 43,517 & $21,614,908$ \\
\hline $\begin{array}{l}\text { Vállalkozások } \\
\text { aránya (\%) }\end{array}$ & $92.4 \%$ & $6.4 \%$ & $1.0 \%$ & $99.8 \%$ & $0.2 \%$ & $100 \%$ \\
\hline $\begin{array}{l}\text { Foglalkoztatotta } \\
\text { k száma }\end{array}$ & $\begin{array}{c}38,629,01 \\
2\end{array}$ & $\begin{array}{c}27,353,66 \\
0\end{array}$ & $\begin{array}{c}22,860,79 \\
2\end{array}$ & $\begin{array}{c}88,843,46 \\
4\end{array}$ & $\begin{array}{c}44,053,57 \\
6\end{array}$ & $\begin{array}{c}132,897,04 \\
0\end{array}$ \\
\hline $\begin{array}{l}\text { Foglalkoztatotta } \\
\text { k aránya (\%) }\end{array}$ & $29.1 \%$ & $20.6 \%$ & $17.2 \%$ & $66.9 \%$ & $33.1 \%$ & $100 \%$ \\
\hline GDP (\%) & $21.6 \%$ & $18.2 \%$ & $18.3 \%$ & $58.1 \%$ & $41.9 \%$ & $100 \%$ \\
\hline
\end{tabular}

2. táblázat. A kis-és középvállalkozások különböző kategóriák szerinti megoszlása Forrás: Eurostat, National Statistical Offices and DIW Econ (letöltés dátuma: 2015.04.02.)

A magyar KKV-k gazdálkodását tehát összességében magas munkaerő- és alacsony tőkeintenzitás jellemzi, de a legnagyobb probléma a hatékonyság. Míg nálunk a mikro vállalkozásokban foglalkoztatottak aránya lényegesen nagyobb, a nagyvállalatoknál foglalkoztatottaké pedig sokkal kisebb. Az EU27 országaiban a kis- és közepes vállalkozások részesedése a hozzáadott érték létrehozásából nagyobb, a nagyvállalatoké ugyanennyivel kisebb. A legnagyobb különbség a termelékenységben mutatkozik. Az EU-27 
országainak átlagos termelékenysége közel háromszor nagyobb, mint a hazai adat. A termelékenységi rés a mikro vállalkozásoknál a legnagyobb, a nagyvállalatoknál a legkisebb. (A kis- és középvállalkozások fejlesztésének stratégiája 2007-2013, Éves Időközi Monitoring Jelentés 2009. év NGKM). Méretük a hazai KKVszektorban tehát, hasonlóan a nemzetközi trendekhez, minden fontos, a versenyképességet jellemző mutató pozitívan korrelál a vállalkozás méretével, a nagyobb cégek tőkeintenzitása magasabb, az alkalmazottaik és a vezetőik képzettebbek, gyakrabban valósítanak meg innovációt, többet fordítanak kutatás-fejlesztésre, jobb eséllyel jutnak külső finanszírozási forrásokhoz, és jobbak a fajlagos eredménymutatóik is. A hazai KKV-szektor további fejlődésének feltétele tehát a méretstruktúra átalakulása és növekvő átlagos vállalatméret. (Kállay, 2012). A stabil szabályozási környezet, a hatékony közvetlen beruházás és foglalkoztatás ösztönzés mellett a KKV-szektor növekedési esélyei akkor a legjobbak, ha megfelelő állami szerepvállalással megfelelő szabályozási környezetben tőkepiaci és banki finanszírozási lehetőségek segítik.

\section{A KKV-K FŐBB FINANSZÍROZÁSI FORRÁSAI}

Annak ellenére, hogy a kis- és középvállalkozások igen fontos szerepet töltenek be minden nemzetgazdaságban, számos problémával kell szembe nézniük. Talán a legjelentősebb problémát a tőkehiány, a finanszírozási forrásokhoz való hozzájutás jelenti. Tanulmányunknak ebben a fejezetében körbejárjuk e problémakört és néhány lehetséges megoldási javaslatra hívjuk fel a figyelmet. Cikkünk, egy jelenleg még zajló kutatást előlegez meg és reménybeli várható eredményeket vetít előre.

A magyarországi kkv-k finanszírozási jellemzőit feltáró primer kérdőíves kutatás a vállalat alapadatainak (méret, ágazat, gazdálkodási adatok, tulajdonosi szerkezet stb.) kérdéscsoportját követően, a vállakozás finanszírozási tapasztalataira gyújt a vállakozásoktól adatokat és kitér a Növekedési Hitelprogram vállalati szempontból történő objektív és szubjektív értékelésére is. A külső forrásokat az alábbi, 5 . ábrán látható formákba sorolja:

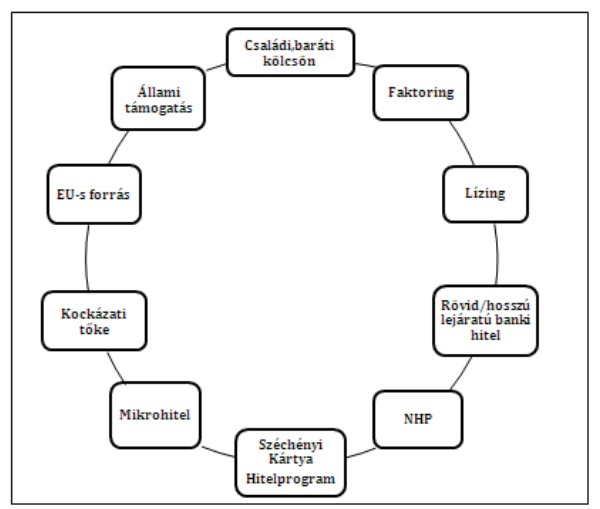

5. ábra. A külső finanszírozási források csoportosítása

Forrás: saját szerkesztés, 2015

A külső források közül a kis- és középvállalkozások vissza nem térítendő támogatások, kölcsönök és - bizonyos esetekben - garanciák formájában juthatnak államilag támogatott külső finanszírozáshoz. Nem kívánjuk megelőlegezni a kérdőív eredményét, de valószínüsíteni lehet, hogy a külső források között a banki hitelek dominanciája a válaszadók értékelésében sem fog változni, ha a hatékonyság növelése a cél. A finanszírozási döntéseknek arra kell irányulnia, hogy sikerüljön forrást találni a folyamatos likviditás, fizetőképesség fenntartására, hogy minimalizálja a súlyozott vállalati tőkeköltséget, illetve, hogy az eszközök és a források lejárati struktúrája összhangban legyen, azaz rövid lejáratú kötelezettségekkel szemben rövid lejáratú források álljanak, a hosszú távú befektetések pedig hosszú lejáratú forrásokkal kerüljenek megvalósításra. A vállalat finanszírozási politikájától függ többek között az elérhető mérleg szerinti eredmény, a vállalat osztalékfizetési képessége, a tőkeszerkezete, az idegen forrás igénye és gyakran a fizetett társasági nyereségadó és a csőd 
Mester Éva - Tóth Róbert

valószínúségének mértéke is. (Csubák Krisztán PhD értekezés, 2003 10. oldal). Érdekes képet mutat az EU Magyarországról szóló 2014. évi
SBA-tájékoztatójának a magyar KKV-k finanszírozáshoz való hozzájutásról szóló fejezete.

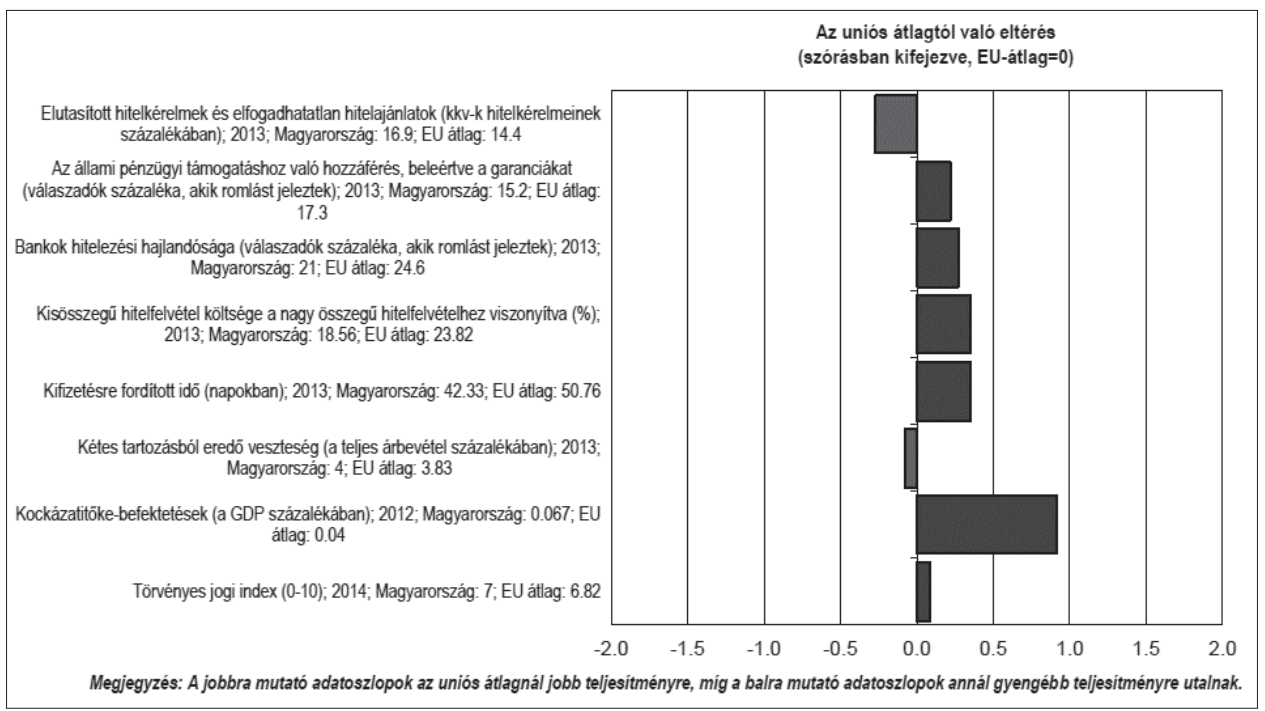

6. ábra. A finanszírozási forrásokhoz való hozzájutás

Forrás: http://ec.europa.eu/enterprise/policies/sme/facts-figures-analysis/performance-review/files/ countries-sheets/2014/hungary_hu.pdf (letöltés dátuma: 2015.04.02.)

Magyarország összesített teljesítménye a KKV-k finanszírozási forrásokhoz való hozzájutása tekintetében megfelel az uniós átlagnak (6. ábra). Ugyanakkor Magyarország a legtöbb egyéni mutató értékén nem javított. A viszonylag jobb helyezés az uniós átlaghoz viszonyítva csupán a finanszírozási feltételek jelentős romlásának köszönhető a többi tagállamban, illetve kisebb mértékben a jegybank által kezdeményezett konkrét finanszírozási konstrukcióknak az eredménye. A Széchenyi Kártya Program és a KKV-k finanszírozását támogató kockázati tőke rendelkezésre állása is élénkítő hatást gyakorolt. Ennek ellenére a legtöbb KKV finanszírozási helyzete továbbra is nehéz. Mint sok más uniós országban, a finanszírozási forrásokhoz való hozzájutás mindig az adott finanszírozási módtól függ. A banki hitelekhez való hozzáférés fokozatosan javult, ugyanakkor drágult is. Míg a kisebb, 1 millió euró alatti - föként KKV-knak szánt - és a magasabb összegú hitelek kamatláb- különbözete alacsonyabb Magyarországon, mint az EU más országaiban, ez a felár a 2007. évi 12\%-ról majdnem 19\%-ra emelkedett 2013-ban. Továbbá az alacsonyabb kamatfelár csak a hitelhez jutó KKV-k esetében jelent előnyt. Az elutasított hitelkérelmek aránya azonban még mindig magasabb Magyarországon, mint más uniós országokban, annak ellenére, hogy 2013ban a 2012. évi $26 \%$-ról 17\%-ra csökkent. A magyarországi KKV-k 28\%- a számolt be arról, hogy a bankok kevésbé hajlandóak hitelt adni nekik (az EU esetében ez az arány $26 \%$ volt). A kormány erélyesebb beavatkozása valamelyest enyhítette ezt a problémát. Ennek köszönhetően a válság kitörése elején, 2008ban mért 31\%-ról 2013-ra 21\%-ra csökkent azon KKV-k részaránya, amelyek a közfinanszírozású támogatásokhoz, többek között a garanciákhoz való hozzáférést nehezebbnek ítélik meg. A többi mutató többékevésbé változatlan maradt. A magyar vállalkozásokat valamivel hamarabb fizetik ki, 
mint uniós társaikat (42 nap az 50 naphoz képest), a kiesett kifizetések aránya (4\%) pedig csaknem azonos az uniós átlaggal. Tehát a cashflow tekintetében a magyarországi KKV-k helyzete nem sokkal rosszabb, mint uniós társaiké.

Pozitív fejlemény a GDP-arányos kockázati tőke fokozatos növekedése az utóbbi években. A legtöbb tagállamhoz hasonlóan kevés KKV jut kockázati tőkéhez, de talán az általános helyzet valamivel kedvezőbb Magyarországon. A helyzeten talán javítottak a JEREMIE I és II programok (A mikro-, kis- és középvállalkozásokat támogató közös európai források) bevezetése a közelmúltban, amelyeknek javítaniuk kellett volna a helyzetet a végrehajtás hatékonyságával kapcsolatos kételyek ellenére (pl. a KKV-k kiválasztása tekintetében).

2013-ban és 2014 első negyedévében különböző eszközök révén mérsékelt eredmények születtek ezen a területen. Először is egy új, kedvezményes kamatozású hitelprogramot vezettek be. A Növekedési Hitelprogram keretében a Magyar Nemzeti Bank forrásokat biztosít a kereskedelmi bankok számára, amelyek a cégeknek szubvencionált támogatást nyújtanak, hogy utóbbiak növelhessék K+F és innovációs kapacitásaikat, és fejleszthessék üzleti környezetüket. Másodszor pedig egy újonnan - az EXIM Bank által biztosított finanszírozási programok keretében - bevezetett hitelkeret révén a KKV-k pénzügyi támogatáshoz jutnak ahhoz, hogy kedvezményes kamatlábbal fejlett gyártóberendezéseket vásárolhassanak (600 millió EUR) exportnövelési céllal.

\section{NÖVEKEDÉSI HITELPROGAM}

A KKV-k hitelezése (az árfolyamhatást kiszűrve) 2008 óta kisebb kilengésekkel, de folyamatosan mérséklődött. (Magyarország Kormánya J/8112. számú jelentés a kis- és középvállalkozások 2009-2010. évi helyzetéről, gazdálkodási feltételrendszeréről, a vállalkozásfejlesztés érdekében megtett intézkedésekről, valamint a kis- és középvállalkozások részére nyújtott állami támogatások eredményeiről. Előadó: dr. Matolcsy György nemzetgazdasági miniszter, Budapest, 2012. július). Az NHP kedvezményes kondíciói (melynek legnagyobb értéke a fix kamat és az elérhető hosszú futamidő), a hitelezési hajlandóságot és a hitelfelvételi kedvet érdemben voltak képesek befolyásolni. A Növekedési Hitelprogram bevezetését megelőzően a hazai KKV-szektor rosszabb helyzetben voltak, mint az Európai Unió más országainak vállalkozásai. Valószínúsíthető, hogy a bankok hitelezési hajlandósága, kockázat vállalása függ attól, hogy a potenciális adós törlesztési terhe hogyan alakul a jövőben, ami függ a kamat nagyságától, a kamatkockázattól, és az esetleges árfolyamkockázattól. Ez a hipotézis azt is vélelmezi, hogy a kedvezőbb kondíciók mellett elérhető hitel a hitelkeresletet a hitelfelvevők oldaláról is élénkíti. Tekintve, hogy az NHP hosszú lejárató, fix, alacsony kamatozású $(2,5 \%$-is kamatszint és 10 éves maximális futamidő) hitelt kínál a magasabb kamatú, többnyire változó kamatozású és rövidebb lejáratú piaci hitelek helyett, alkalmas a tényleges hitelkereslet és a valós ügyfélkockázat felmérésére is.

A Növekedési Hitelprogram teljes fordulatot hozott a hazai KKV-szektor hitelezésében (7. ábra). A statisztikai adatok szerint trendtörés következett be a vállalati, és ezen belül a KKVhitelezési folyamatokban. Míg korábban évente 4-6 százalékkal zsugorodott az állomány, 2013 harmadik negyedéve óta gyakorlatilag stagnál, ami döntően az NHP hatásának köszönhető. Több vállalati felmérés is arról tanúskodik, hogy a hitelezés élénkülése jelentős része a keresleti oldalról is jelentkezik: a hitelprogramban résztvevő vállalatok jelentős része piaci alapon nem, vagy csak kisebb összegben vett volna fel hitelt. A 2013. évben indult NHP már az első pillére rövid időn belül (3-5 hónap) kifejtette pozitív hatását a kis-és középvállalkozások hitelállományában. A program hatásának köszönhetően a teljes hitelintézeti szektor 
Mester Éva - Tóth Róbert

vállalatihitel-állományának nettó változása megközelítette a 600 Mrd. Ft-ot (8. ábra).

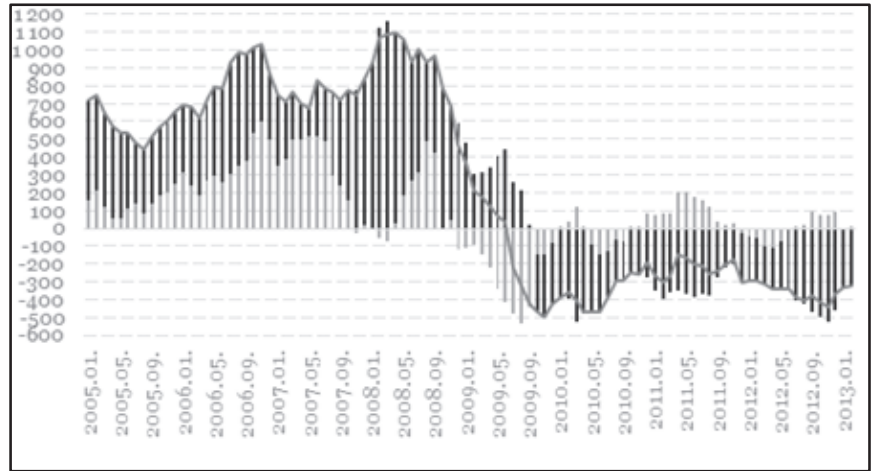

7. ábra. Kihelyezett vállalati forinthitelek és devizahitelek 12 havi gördülő nettó összege illetve összesen (mrd Ft)

Forrás: MNB - Növekedési Hitelprogram tájékoztató- portfolio.hu (letöltés dátuma: 2013.04.29.)

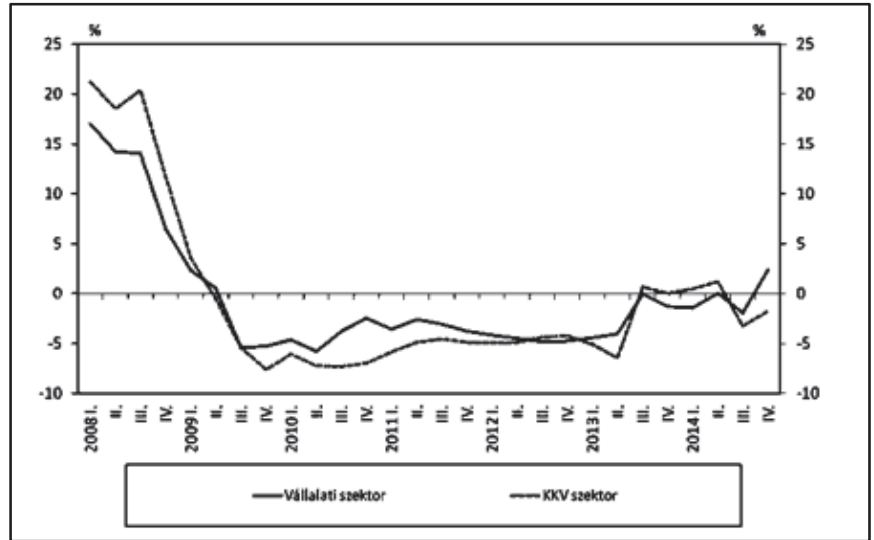

8. ábra. A teljes vállalati és a kkv-szektor hitelállományának növekedési üteme

Forrás: http://www.mnb.hu/Kiadvanyok/hitelezesi-folyamatok/hitelezesi-folyamatok-2015-marcius (letöltés dátuma: 2015.04.02.)

A primer kérdőívben szeretnénk rávilágítani arra is, hogy a fix alacsony kamat jelentett- $e$ horgonyhatást a piaci hitelek kamata és a megfelelően hosszú futamidő tekintetében, illetve javította-e a párbeszédet a finanszírozó bankok és az ügyfelek között. Fontos hangsúlyozni, hogy az NHP célja egy átmeneti időszakban stimulálni a hitelezést, nem pedig végérvényesen felváltani, helyettesíteni a piacot. A pénzügyi közvetítőrendszernek át kell vennie az irányítást, középtávon a piaci alapon történő hitelezés élénkülhet, a gazdasági növekedéssel pedig a hitelkereslet egészséges élénkülése következhet be.

\section{A PIACI FINANSZÍROZÁS SZEREPLŐI ELŐTT ÁLLÓ KIHÍVÁSOK}

Évek óta hitelezési egyensúlytalanságban van a magyar KKV hitelpiac. 2008-ig egy felfokozott aranykorban tudhatta magát, köszönhetően az alacsony forrásköltségeknek, a csökkenő kockázati költségeknek és az alacsony hozamelvárásoknak. A tőkepiaci aktivítás növekedett. (2013. május 8. Portfolio.hu 
konferencia a hitelezésről / Élő halott a hitelezés - Egy konferencia tanulságai). A növekedés elfedte a szektor 2000 évek óta felerősödött struktúrális problémáit: megfelelő méretszerkezetének, tőkeintenzításának, innovativ képességének hiányosságait. Kevésbé volt érzékelhető a gyorsan változó jogi és számviteli szabályozásunkban rejlő bizonytalansági tényező is. Ez tört meg 20082009-ben, hatalmasat zuhant a hitel/GDP arány és a csökkenés kisebb kilengéseket leszámítva talán most állt meg. A kereslet részben visszatért, a piaci banki kínálat azonban ettől lemaradva hiányzik. Az elmúlt évek veszteségsokkjai után és az újabb bizonytalanságok miatt a piaci finanszírozási költségek még nem térnek vissza a válság előtti alacsony szintjükre. A bankszektor küszködik - és különböző elemzéseket végez (3. táblázat) -, hogy elérje a tulajdonosok és a piacok által elvárt hozamot, ellenben korántsem biztos, hogy a bankok képesek lesznek a korábbi hatékony formában eljuttatni a megtakarításokat a hitelfelvevőkhöz. (Dietz, 2012)

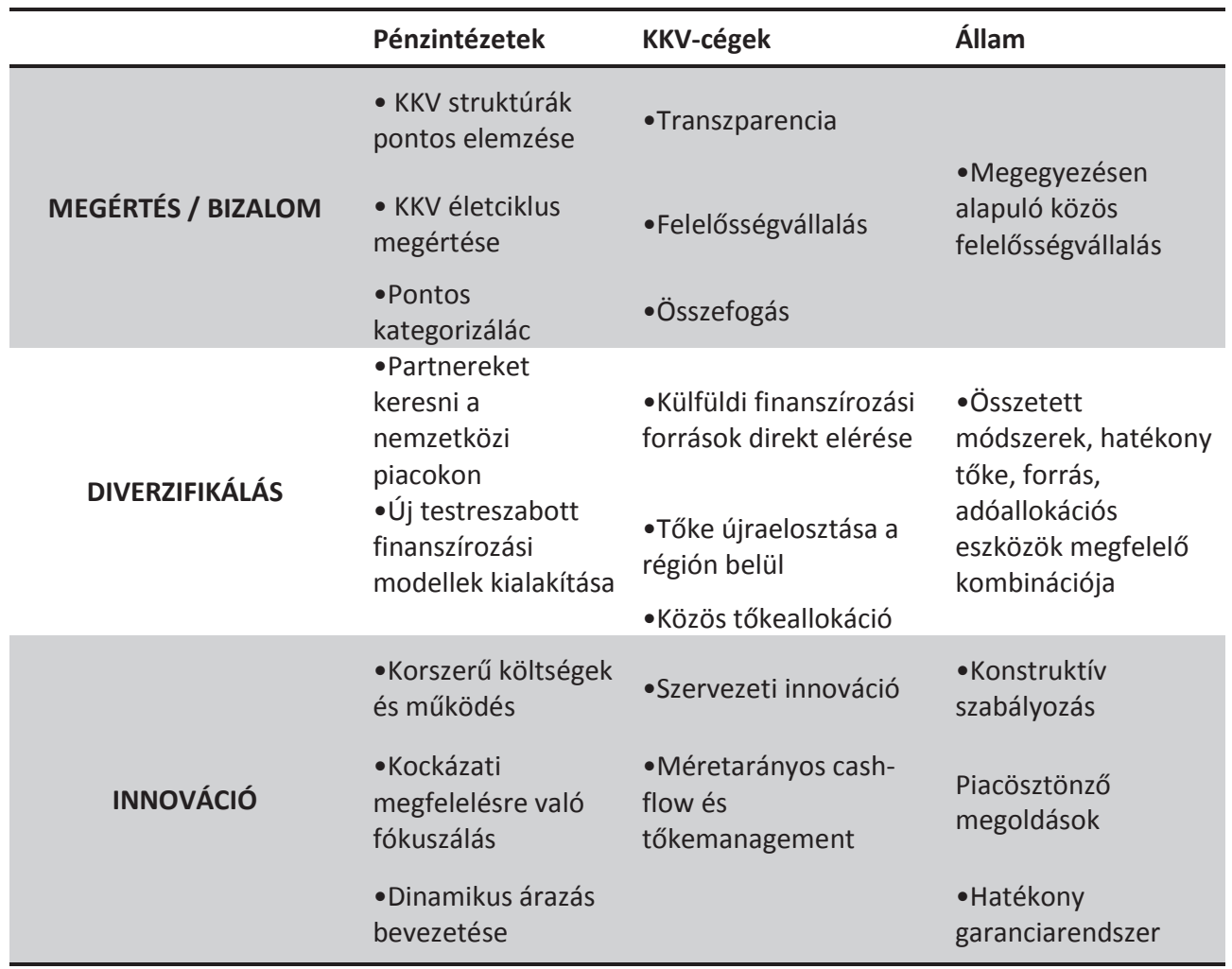

3. táblázat. A piac résztvevőinek elemző vizsgálata kiemelt szempontok alapján

Forrás: http://www.hvca.hu/hu/2015/02/a-magyar-nemzeti-bank-elemzése ( letöltés dátuma: 2015.04.02.)
9. A TŐKEPIAC
JELLEMZŐ।
A bankszektorhoz hasonlóan a 2008-ban MAGYARORSZÁGON bekövetkezett válság hatására a tőkepiaci aktivítás is drámaian zuhant, a külföldi tőkealapok szinte kivétel nélkül visszavonultak Magyarországról. Ennek oka nagyrészt a 
bizonytalan gazdasági helyzet, másrészt az egyes elérhető tranzakciók rendkívül alacsony méretnagysága volt. A 2009-ben meghirdetett első JEREMIE1 programnak köszönhetően a hazai private equity (PE) iparág - pontosabban annak korai stádiumú befektetésekkel foglalkozó, venture capital (VC) szegmense - új lehetőséget kapott. A program révén 2009 és 2010 évek folyamán több kockázati tőkealapkezelő és kockázati tőkealap jött létre, amelyek a korai fázisú befektetések tekintetében hiánypótló szerepet töltöttek be. A korai stádiumú befektetések jelentősége a hazai piacon a 2000-es években elenyésző volt és döntő részben a JEREMIE alapoktól érkező források teremtették meg annak a lehetőségét, hogy a korai életciklusú, innovatív, kisméretú vállalkozások tókéhez jussanak.
Ez látható a 4. táblázat 2010 évi adataiban, mely nagyobb darabszámú, de kis összegú befektetést regisztrál (2010 nem lezárt év).

Az elmúlt évek során a JEREMIE alapok befektetési aktivitása fokozódott, illetve időközben a szegmens is tovább bővült, mivel a 2012-ben meghirdetett második JEREMIE program keretében 2013-ban és 2014-ben újabb kockázati tőkealap-kezelők és kockázati tőkealapok jöttek létre. A 9. ábra a hazai PE szektor 2010. január 1. és 2014. június 30. közötti befektetési aktivitását mutatja.

\begin{tabular}{|l|r|r|r|}
\hline Befektetés éve & $\begin{array}{c}\text { Befektetett } \\
\text { tôke értéke } \\
\text { (millió Ft) }\end{array}$ & $\begin{array}{c}\text { Befektetési } \\
\text { ügyletek } \\
\text { száma (db) }\end{array}$ & $\begin{array}{c}\text { Átlagos befekte- } \\
\text { tési érték (millió } \\
\text { Ft) }\end{array}$ \\
\hline 2007. & 123393,7 & 26 & 4749,8 \\
\hline 2008. & 119847,2 & 25 & 4773,8 \\
\hline 2009. & 60043,5 & 12 & 4994,3 \\
\hline 2010. & 17901,8 & 19 & 936,4 \\
\hline
\end{tabular}

4. táblázat. JEREMIE alapokból érkező források (2007-2010)

Forrás: http://www.hvca.hu/hu/2013.03/statisztika (letöltés dátuma: 2015.04.02.)

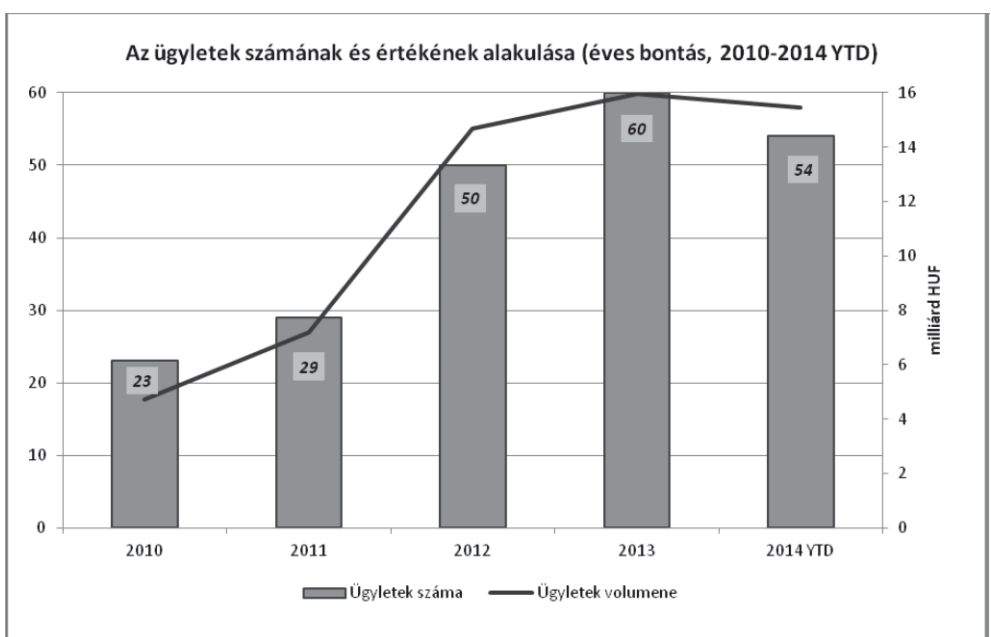

9. ábra. A hazai PE szektor befektetési aktivitása (2010-2014)

Forrás: http://www.hvca.hu/hu/2015/02/a-magyar-nemzeti-bank-elemzése (letöltés dátuma: 2015.04.02.) 


\section{NÉHÁNY SZÓ A CROWFUNDINGRÓL}

Egyes vélemények szerint a crowdfunding paradigma-váltást eredményezhet - hiszen az innovatív gondolkodásmóddal abszolút konform ez a megoldás - amely folyamatból nem lenne célszerű kimaradni. Egyetlen óriási hátránya van: ellenőrizhetetlen. A crowdfunding a kockázati tőke versenytársának tekinthető -, de egy alap túl sokat „kér” (túl magas a kockázatokat visszatükröző diszkont), ott van a vállalat menedzsmentjében, ráadásul még ellenőriz is. Ennek következtében a finanszírozást kereső vállalat inkább kisbefektetőktől próbálja összegyújteni a tőkét. A magyar retail piac egyrészt abszolút nem elég edukált ahhoz, hogy megértse a crowdfundinghoz kapcsolódó kockázatokat, másrészt a hazai retail befektetők között jelenleg elenyésző azok aránya, akik egyrészt rendelkeznek érdemi megtakarítással egy ilyen jellegű befektetésre, továbbá nyitottak is az ilyen jellegú befektetések iránt. Megtakarítások, illetve kellő nyitottság hiányában, akik nemzetközi termékekben vagy projektekben gondolkodnak, azok előbb-utóbb valamelyik nemzetközi portálon fognak megjelenni (többek között a Kickstarter-en). A hazai piacon még nem alakult ki az ehhez szükséges üzleti, bizalmi és vállalati kultúra, ezért aki crowdfunding által szeretne nagyobb tőkét gyújteni az el fog menni a külföldi piacra. Egyes vélemények szerint a hazai piacon sokkal inkább elképzelhető az, hogy üzleti angyalok érdeklődését kelti fel valamely ötlet vagy projekt, akik bizonyos volumenben (1-5 millió Ft közötti értékben) hajlandóak lesznek ezeket megfinanszírozni. Kizárólag vállalkozói oldalról nézve ez egy nagyon támogatható dolog, hiszen miért ne próbálhatná meg valaki eladni az ötletét másoknak. A crowdfunding egyik előnye, hogy nagyon rugalmas, viszont nagyon nehéz a folyamatból kiszúrni azokat, akiket elsősorban nem gazdasági érdek motivál. Minél vadabb egy innováció, annál nagyobb a csalás valószínúsége. Ennek következtében itt a megfelelő, transzparens és hiteles riportolás jelentősége óriási. A leírtak alapján látható, hogy a crowdfunding esetében nagyon sok faktort kell nagyon óvatosan mérlegelni, amelynek során a szabályozók felelőssége is igen jelentős.

\section{1. ÖSSZEGZÉS - LEHETSÉGES VÁLASZOK A KIHÍVÁSOKRA}

Az alábbi cikk keretében arra vállalkoztunk, hogy röviden rávilágítsunk a magyar mikro-, kisés középvállalati szektor aktuális gazdasági helyzetére, valamint finanszírozásának lehetőségeire. A primer kutatás következtetései remélhetőleg választ adnak arra, hogy a feltevések milyen kombinációja múködőképes és mely megoldások és milyen arányban vezetnének hatékonyabb struktúra kialakításához.

A hitelezési egyensúlytalanság megoldását a banki szektoron belül és kívül egyaránt lehet tehát keresni, azonban különböző problémák különböző összefüggéseket tárnak fel. Óriási különbség van az egyes lehetséges kimenetelek között:

- nem tud eljutni a tőke a gazdasághoz, csökken a növekedési ütem,

- az állam növeli gazdasági aktivitását, egy ilyen tőke vagy forrásallokáció azonban csak jóval kevésbé hatékony lehet a piacinál, ezért átmenetileg tud csak kellő ösztönzést adni a hitelezésnek,

- az árnyék bankrendszer próbálja betölteni az ürt (shadow banking),

- nem a bankok, hanem egyéni befektetők finanszírozzák egymást (crow funding).

Mit tehetnek a bankok: jelentős expanziót kell végrehajtaniuk a tradicionális hitel és befektetői piacon, innovativ, alacsony árazású alternatívákat kínálva új és biztonságos biztosítékokat alkalmazva. ROE és COE kérdésében jelentősen redukálniuk kell a költségeiket, további konszolidációkat kell végrehajtani, hálózatcsökkentést kell végrehajtani, külső piacokat kell keresniük. Legfőképpen viszont a növekedés érdekében a banki piacnak innovatívabbnak kell lennie, meg 
Mester Éva - Tóth Róbert

kell ismernie legfontosabb piacát és azok életpályája szerinti igényeket kell kielégítenie. Továbbá központi kérdésként kell kezelni azt a tényt is, miszerint érdemi hitelkeresletnövekedés abban az esetben lehet elérni, amennyiben megerősödik a piaci bizalom és stabil gazdasági jövőképet helyeznek a bankok a vállalati szféra elé.

Mit tehet az állam: optimálisan kell ötvözie ösztönzőrendszerében a hatékony banki tőkeallokációt és a konstruktív szabályozó eszközöket: pozitív, hitelezést segítő banki adórendszer, hatékony intézményi garanciarendszer, kamat kiegyenlítő módszerek alkalmazásával. Közvetlen bankoknak nyújtható vagy ügyféllel kombinált piacösztönző megoldásokat kell továbbra is keresnie és azokat megfelelő méretben alkalmazza. Átvizsgálni a KKV-at érintő jogi és számviteli környezetet és azokat a gazdasági ösztönzés érdekében alakítania.

Mit tehet a KKV-szektor: a megfelelő méretarányos cash flow és tőkemanagement mellett a legfontosabb a transzparencia, a felelősségvállalás és az összefogás erősítése, melynek ki kell egészülnie a szervezeti innováció jelentős fejlesztésével. Innoválni azonban csak akkor tudnak a vállalkozások, ha megfelelő humán-tőkével rendelkeznek. Mindez pedig abban az esetben valósítható meg, amennyiben - az állami szerepvállalás mellett - a gazdálkodó szervezetek is támogatják a munkavállalóik folyamatos képzését.

\section{FELHASZNÁLT IRODALOM}

[1] BÉZA D. - CSUBÁK T. K.[2005]: Kisvállalkozások pénzügyei. Budapesti Corvinus Egyetem Kisvállalkozás fejlesztési Központ, egyetemi jegyzet

[2] CHIKÁN A. -DEMETER K. (szerk.) (1999): Az értékteremtő folyamatok menedzsmentje. Budapesti Közgazdaságtudományi és Államigazgatási Egyetem, Aula Kiadó Kft., Budapest.

[3] CSUBÁK T. K. [2008]: A Magyar kkv-hitelezés tendenciáinak áttekintése a 2001-2007 közötti időszakban. 60 éves a Közgáz Jubileumi Konferencia Kötet

[4] Csubák T. K. (2003): Kis- és középvállalkozások finanszírozása Magyarországon. Budapesti Corvinus Egyetem.

[5] Deloitte. UK \& European restructuring market outlook 2015 - A split forecast

[6] Dietz M. partner (2012): Hitelezés Magyarországon címú konferencia előadása

[7] Dr. Matolcsy Gy. (2012): J/8112. számú jelentés a kis- és középvállalkozások 2009-2010. évi helyzetéről, gazdálkodási feltételrendszeréről, a vállalkozásfejlesztés érdekében megtett intézkedésekről, valamint a kis- és középvállalkozások részére nyújtott állami támogatások eredményeiről, Magyarország Kormánya

[8] DR. MATOLCSY GY. (2015):Egyensúly és Növekedés, Konszolidáció és stabilizáció Magyarországon 2010-2014, Kairosz Kiadó

[9] Dr. Szabó A. (2010): Kis- és középvállalkozások helyzete Magyarországon

[10] Élő halott a hitelezés - Egy konferencia tanulságai (2013) www.portfolio.hu

[11] European Comission [2014]: A partial and fragile recovery - Annual report on european SMEs 2013/2014. hely nélk. : European Union

[12] Gyenge B., Kozma T., Bíró T. (2014): Pénzügyi helyzet elemzés a vállalati életciklus szakaszaiban, CONTROLLER INFO II.:(2) pp. 27-31.

[13] GYENGE B., BURESH J., KOZMA T. (2013): How to Measure the Efficiency of Management Strategy in Organisational Structure. In: Bylok, F. at al. (szerk.) HUMAN CAPITAL AND CORPORATE RESPONSIBILITY. Politechniki Czestochowskiej,. Czestochowa, Lengyelország pp. 60-72. 
[14] FÁBIÁN G. - FÁYKISS P. - SZIGEL G. [2011]: A vállalati hitelezés ösztönzésének eszközei, MNB tanulmányok

[15] KÁLLAY L. - KISSNÉ KOVÁCS E. - KŐHEGYI K. - MASZLAG L.[2005]: A kis- és középvállalkozások helyzete. Éves jelentés 2003/2004. Budapest: Gazdasági és Közlekedési Minisztérium

[16] Kállay L. (2012): KKV-szektor: versenyképesség, munkahelyteremtés, szerkezetátalakítás. Műhelytanulmány (working paper). Vállalatgazdaságtan Intézet, Budapest.

[17] KSH Gyorsjelentés 2014. November A kis és középválalkozások jellemzői

[18] Márton A. (2012): A KKV szektor számvitele és a társasági adórendszer kapcsolatának vizsgálata a Magyar gyakorlatban

[19] MNB [2013]: Növekedési Hitelprogram bemutatása http://www.mnb.hu/Root/Dokumentumtar/MNB/Kiadvanyok/szakmai_cikkek/hitelezes nhp/KKV_cikk_final_final.pdf

[20] NEMZETGGAZDASÁGI MINISZTÉRIUM, http://www.kormany.hu/hu/nemzetgazdasagiminiszterium/videok/a-magyar-kkv-k-ketmillio-embernek-biztositanak-munkahelyet

[21] NGKM [Nemzetközi Gazdasági Kapcsolatok Minisztériuma]: A kis- és középvállalkozások fejlesztésének stratégiája 2007-2013

[22] Pulay Gy. - Máté J. - Németh I. - Zelei A. (2013): A monetáris politika kockázatai és az államadósság-szabály, Pénzügyi Szemle

[23] Statisztikák (http://www.hvca.hu/hu/statisztika/)

[24] Szerb L. [2008]: A haza kis- és középvállalkozások fejlődését és növekedését befolyásoló tényezők a 2000-as évek közepén. Vállalkozás Innováció 2. évfolyam 2. szám. : ismeretlen szerző, 2008. II. negyedév.

[25] Vágány J. - Kárpátiné Daróczi J. [2011] - A gazdasági világválság kihívásai és a kilábalás lehetőségei a kkv-k számára, Általános Vállalkozási Főiskola, Budapest

[26] Vörös M. (2012): Állami támogatás a magyar kkv-szektorban: miből mennyi jut?

[27] Walter Gy. [2014]: Vállalatfinanszírozás a gyakorlatban. Budapest: Alinea Kiadó 